\title{
IFAS Community Development: Empowering Your Community, Stage 3, Goal Setting and Strategy Formulation ${ }^{1}$
}

\section{M.A. Brennan ${ }^{2}$}

This paper is part of a series of discussions on community development. This series includes specialized papers on civic engagement, community action, and other topics important to the development of community.

\section{Introduction}

Based on the previous stages of action (Initiation and Organization of Sponsorship) organized local residents are then ready to move forward in the formulation of action plans (Wilkinson, 1991; Theodori, 2004; Marcus and Brennan, 2005; Brennan and Regan, 2005). In this stage, Goal Setting and Strategy Formulation, the group develops a common vision and establishes measurable means for achieving this vision. Such plans and action transcend the individual self-interest of participants, as well as those of the groups or organizations that they represent. The goal setting and strategy formulation process reflects the tangible and measurable general needs of the entire locality.

\section{The Goal Setting and Strategy Formulation Process}

The formulation of goals and strategies is vital to the development of effective action and community development efforts (Wilkinson, 1970; Wilkinson, 1991; Luloff and Bridger, 2003). To begin this process, the forces shaping the community must be identified. Relevant issues can be the deficiencies and needs of the community, such as the need for improved infrastructure, service opportunities, housing, or jobs (needs assessments). While negative issues are often the focus of attention, this need not always be the case. Plans for action often emerge out of an assessment of local skills, niche markets, and unique local conditions present (asset mapping). A combination of goals/objectives that include both needs and assets is often effective because they show the obstacles facing localities, but also the unique capacity that local people have for overcoming these obstacles. By assessing the relevant issues and assets and then ranking them in relation to importance and potential for achieving change, local groups can develop a vision and action agenda. This

1. This document is FCS9228, one of a series of the Family, Youth and Community Sciences Department, Florida Cooperative Extension Service, Institute of Food and Agricultural Sciences, University of Florida. Original publication date September 2005. Visit the EDIS Web Site at http://edis.ifas.ufl.edu.

2. M.A. Brennan, Assistant Professor of Community Development, Department of Family, Youth and Community Sciences, Florida Cooperative Extension Service, Institute of Food and Agricultural Sciences, University of Florida, Gainesville, FL, 32611.

The Institute of Food and Agricultural Sciences (IFAS) is an Equal Opportunity Institution authorized to provide research, educational information and other services only to individuals and institutions that function with non-discrimination with respect to race, creed, color, religion, age, disability, sex, sexual orientation, marital status, national origin, political opinions or affiliations. U.S. Department of Agriculture, Cooperative Extension Service, University of Florida, IFAS, Florida A. \& M. University Cooperative Extension Program, and Boards of County Commissioners Cooperating. Larry Arrington, Dean 
vision will serve as the general focus for action and community development efforts.

\section{Building Goal Setting and Strategy Formulation into Extension}

Extension professionals or agents of change can help local residents identify key issues, evaluate local assets, and aid in the development of action agendas by local residents. Useful steps can include:

\section{Identification of Issues, Needs, and Assets}

By bringing together the residents identified in Step 1 (Initiation) and Step 2 (Organization of Sponsorship), a broad based representation of the community is in place. This group should be able to speak to the wide range of needs, issues, and assets present in the locality. Participants can be asked to list these, and then the overall group can discuss and rank the list in terms of importance, as well as the feasibility of successfully achieving change. This process of assessing local conditions, can take place in individual meetings or over the course of several sessions, depending on the complexity or scope of conditions facing the locality. The end result of these sessions should be an agreed upon vision of what participants think the community should look like.

\section{Establishing Priorities and Organizing Participants}

Based on the issues and assets identified, local residents can begin to develop plans to achieve community change. Once a rating and prioritization of issues and assets has taken place, specific measurable and achievable goals should be established. In practice, most action efforts will contain more than one area of focus. To adequately address these multiple areas and to establish goals for achieving change for each, it is useful to form subgroups or committees. Membership on these groups can be on a volunteer basis or members can be appointed based on their specific skills, experiences, or other characteristics (these can be documented through asset mapping and other activities).

While these subgroups are operating individually, it is essential that they be directly linked to the mission of the overall group and the goal of community development. Included in the actions of this group can be the collectors of local data on a particular issue (scope of problems, changes in populations, number of people impacted, local resources available to meet needs). The goal of these subgroups should be to compile usable and manageable data that can give insight into areas for local grassroots action.

\section{Review of Data and Other Relevant Resources}

Using the data compiled by the subgroups, a detailed overview of the factors shaping a particular local issue can be developed. This data and findings can be presented to the overall group, and potential scenarios to achieve change should be discussed. This diverse group of local residents can bring unique and nontraditional options for development to the table, which in other settings might not be heard. Included in this process can be the introduction of Extension and other subject matter experts to present programs and curriculum that have been useful in similar situations.

\section{Visioning, Goals, and Strategy Formulation}

With solid data in hand and a clear understanding of the issues, each subgroup can then develop their own vision statements, goals, and clearly defined strategies for addressing their goals. These are defined as:

- Vision statements: long range descriptions of the community and what local people want it to be.

- Goals: clearly defined and measurable, including milestones and logically attainable achievements.

- Strategies: special projects, step-by-step methods for achieving goals, plans for mobilizing resources, and plans for drawing cross-community support. 


\section{Presentation of Goals and Strategies to Organizing Groups}

Following the formulation of ideas for subgroup visions, goals, and strategies, a need exists for these to be presented to the larger group for feedback and constructive contributions from all group members. This allows for adjustments and improvements to the original plans. Obviously, depending on the group, this can take considerable time. At times, it may be effective to distribute discussions of goals and objectives over more than one meeting. It may also be useful to elicit comments and responses through e-mail, fax, and other flexible means. The more feedback that can be provided, the better the plans for action will be.

\section{Conclusion}

The organization of goals, visions, and strategies for change are vital to the long-term success of local community development and action efforts (Wilkinson, 1970; Luloff and Bridger, 2003; Theodori, 2004; Brennan, 2005). While plans for action can be changed over time, it is essential that, from the beginning, they be reflective of local needs and capacities. This allows more holistic plans of action to be developed and implemented. The goal setting and strategy formulation stage is essential in that it provides a clearly defined strategy for enhancing local well-being. This vision and strategy is a solid basis for the next stage, Recruitment, which provides active local citizens with a framework for involvement in efforts to improve local well-being.

\section{References and Useful Reading}

Brennan, M. A. 2005. The Importance of Local Community Action in Shaping Development. [online]. EDIS. Gainesville, FL: Cooperative Extension Service, Institute of Food and Agricultural Sciences, University of Florida. http://edis.ifas.ufl.edu/FY729

Brennan, M. A. and C. Regan. 2005. Empowering Your Community, Stage 2, Organization of Sponsorship. [online]. EDIS. Gainesville, FL: Cooperative Extension Service, Institute of Food and Agricultural Sciences, University of Florida. http://edis.ifas.ufl.edu/FY763
Luloff, A.E., and J. Bridger. 2003. Community Agency and Local Development. Pp. 203-213 in, Challenges for Rural America in the Twenty-First Century, edited by D. Brown and L. Swanson. University Park, PA: Pennsylvania State University Press.

Marcus, J. and M.A. Brennan. 2005. Empowering Your Community, Stage 1, Initiation. [online]. EDIS. Gainesville, FL: Cooperative Extension Service, Institute of Food and Agricultural Sciences, University of Florida.

http://edis.ifas.ufl.edu/FY740

Theodori. G. 2004. Preparing for the Future: A Guide to Community Based Planning. College Station, TX: Texas A\&M University Cooperative Extension Service.

Wilkinson, K. 1970. "Phases and roles in community action." Rural Sociology. 35 (1): 54-68.

Wilkinson, K.P. 1991. The community in rural America. New York, NY: Greenwood Press, 1991.

\section{Useful Websites}

Community: A Biography in Honor of the Life and Work of Ken Wilkinson.

http://www.cas.nercrd.psu.edu/Community/ community.html

Community Development Institute East. http://www.ext.wvu.edu/cdi-east/

The Community Development Society. http://www.comm-dev.org/

Community Resource Group. http://www.crg.org/

Civic Practices Network. http://www.cpn.org/

Grass-roots.org. http://www.grass-roots.org/

International Association for Community

Development. http://www.iacdglobal.org/

Mapping the Assets of Your Community: A Key Component for Building Local Capacity http://srdc.msstate.edu/training/trainingcurricula.htm 
Southern Rural Development Center.

http://srdc.msstate.edu

Sustainable Development Communication

Network. http://www.sdgateway.net 